\title{
DIURNAL FLUCTUATIONS IN THE NUMBERS OF DNA SYNTHESIZING NUCLEI IN VARIOUS MOUSE TISSUES
}

\author{
By C. PILGRIM, W. ERB and W. MAURER \\ Institut für Med. Isotopenforschung der Universität, Köln, Germany
}

\begin{abstract}
I $\mathrm{T}$ has often been shown that the mitotic rates reveal marked diurnal fluctuations in various tissues of many organisms. In rats and mice the mitotic rates often seem to reach a maximum at night and a minimum during the day. Bullough has given two reviews of this subject and has discussed, in terms of waking and sleeping, the possible causes of these waves of activity ${ }^{1,2}$.

This investigation was undertaken to discover whether the number of nuclei in DNA synthesis ( $S$-phase) is also subject to diurnal fluctuations. Mice were injected intraperitoneally with tritiated thymidine $(0.7 \mu \mathrm{c} . / \mathrm{g})$ at intervals throughout the day. Before and during the experiments the animals were kept under constant conditions and were fed ad libitum. Forty min after the injection the animals were killed by decapitation. Autoradiographs were prepared (Ilford 65 emulsion) from $3-\mu$ thick paraffin sections of various tissues. Then the percentage of labelled nuclei (tritium index) and the percentage of cells in mitosis (mitotic index) were estimated. In addition, the mean grain number was counted in nuclei which had been cut approximately centrally. The results of one series of experiments are shown in Table 1. The figures are the average values from two animals, which showed little variation from the mean. In addition, the results were confirmed by a second series of experiments.
\end{abstract}

Table 1. Trixiom Index, Mitotic Index and Mean Grain Count Per

\begin{tabular}{|c|c|c|c|c|}
\hline Tissue & $\begin{array}{c}\text { Hour of } \\
\text { day }\end{array}$ & $\begin{array}{l}\text { Tritium } \\
\text { index }(\%)\end{array}$ & $\begin{array}{l}\text { Mitotic } \\
\text { index }(\%)\end{array}$ & $\begin{array}{l}\text { Grains per } \\
\text { nucleus }\end{array}$ \\
\hline $\begin{array}{l}\text { Csophagus } \\
\text { strat. bas. }\end{array}$ & $\begin{array}{r}5.30 \\
11.30 \\
17.30 \\
23.30\end{array}$ & $\begin{array}{l}1 \cdot 5 \\
1 \cdot 0 \\
6 \cdot 4 \\
3 \cdot 7\end{array}$ & $\begin{array}{l}0.83 \\
0.14 \\
0.19 \\
0.14\end{array}$ & $\begin{array}{l}9 \cdot 2 \\
9 \cdot 5 \\
9 \cdot 7 \\
9 \cdot 5\end{array}$ \\
\hline $\begin{array}{l}\text { Fore-stomach } \\
\text { strat. bas. }\end{array}$ & $\begin{array}{r}5.30 \\
11.30 \\
17.30 \\
23.30\end{array}$ & $\begin{array}{l}3 \cdot 9 \\
3 \cdot 0 \\
5 \cdot 5 \\
3 \cdot 8\end{array}$ & $\begin{array}{l}1 \cdot 18 \\
0.38 \\
0 \cdot 35 \\
0 \cdot 42\end{array}$ & $\begin{array}{l}9 \cdot 9 \\
9 \cdot 5 \\
9 \cdot 6 \\
9 \cdot 6\end{array}$ \\
\hline $\begin{array}{l}\text { Abdominal skin } \\
\text { epidermis }\end{array}$ & $\begin{array}{r}5.30 \\
11.30 \\
17.30 \\
23.30\end{array}$ & $\begin{array}{l}1 \cdot 7 \\
1 \cdot 0 \\
4 \cdot 5 \\
2 \cdot 7\end{array}$ & $\begin{array}{l}0.47 \\
0 \cdot 18 \\
0 \cdot 21 \\
0.19\end{array}$ & $\begin{array}{r}9 \cdot 1 \\
9 \cdot 5 \\
8 \cdot 9 \\
10 \cdot 2\end{array}$ \\
\hline $\begin{array}{l}\text { Tongue } \\
\text { strat. bas }\end{array}$ & $\begin{array}{r}5.30 \\
11.30 \\
17.30 \\
23.30\end{array}$ & $\begin{array}{r}4 \cdot 9 \\
4 \cdot 3 \\
20 \cdot 7 \\
9 \cdot 9\end{array}$ & $\begin{array}{l}1.01 \\
0.17 \\
0.25 \\
0.59\end{array}$ & $\begin{array}{l}9 \cdot 7 \\
9 \cdot 9 \\
9 \cdot 6 \\
9 \cdot 6\end{array}$ \\
\hline $\begin{array}{l}\text { Jejunum } \\
\text { crypt. epith. }\end{array}$ & $\begin{array}{r}5.30 \\
11.30 \\
17.30 \\
23.30\end{array}$ & $\begin{array}{l}43 \\
42 \\
44 \\
41\end{array}$ & $\begin{array}{l}4 \cdot 8 \\
4 \cdot 7 \\
3 \cdot 8 \\
4 \cdot 7\end{array}$ & $\begin{array}{l}9 \cdot 6 \\
9 \cdot 2 \\
9 \cdot 6 \\
9 \cdot 8\end{array}$ \\
\hline $\begin{array}{l}\text { Kidney } \\
\text { convol. tub. }\end{array}$ & $\begin{array}{r}5.30 \\
11.30 \\
17.30 \\
23.30\end{array}$ & $\begin{array}{l}1 \cdot 2 \\
1 \cdot 2 \\
1 \cdot 2 \\
1 \cdot 1\end{array}$ & 二 & $\begin{array}{l}9 \cdot 8 \\
9 \cdot 9 \\
9 \cdot 2 \\
9 \cdot 1\end{array}$ \\
\hline
\end{tabular}

It will be seen that no diurnal fluctuations in the mitotic index were present in the epithelia of the jejunal crypts. However, in the other epithelia of the digestive tract (tongue, œsophagus, forestomach) and in the abdominal epidermis diurnal fluctuations were obvious, a finding which agrees with the results of other authors ${ }^{3}$. It will also be seen that the tritium index shows similarly large fluctuations. Again, however, an exception is provided by the intestinal epithelium and also, in this case, by the tubuli contorti of the kidney. Thus, depending on the time of day, a partial synchronization is apparent in the $S$-phase nuclei precisely as can be seen in the mitoses.

The observed fluctuations in the tritium-index could be caused by diurnal fluctuations of the duration of DNA synthesis since an increase in the duration of DNA synthesis would result in an increase of the tritium index. However, according to Table 1, the mean grain number per nucleus does not show any diurnal fluctuation suggesting that the rate of synthesis, and therefore also the duration of synthesis, is constant. Thus the most probable explana- tion for the variations in the tritium index is that the number of nuclei entering $S$-phase from $G_{1}$-phase per unit time depends on the time of day.

From many of the papers previously published ${ }^{2}$ the impression may be gained that the diurnal fluctuations in the mitotic index are directly due to parallel fluctuations in the triggering process of mitosis. In this case one would expect later on, during the following generationcycle (that is, after the end of $G_{1}$-phase), to find a certain accumulation of $S$-phase nuclei. But it is very improbable that the observed fluctuations of the tritium index can be explained this way. For the rather sharp maximum of the tritium index would be difficult to understand since the $G_{1}$-phase requires several days in the cell types studied here and is certainly subject to additional individual variations. Furthermore, the fact that the time-interval between the tritium and the mitotic index is of similar size in all examined cell types would not fit into this theory.

It is much more likely that the primary process consists of a synchronization of $S$-phases. Consequently, one would expect an increase in the mitotic figures some hours later. The time-interval between the two maxima should be equal to $=1 / 2 S$-phase $+G_{2}+1 / 2$ duration of mitosis. Unfortunately only incomplete data concerning the $G_{2}$-phase of the examined cell types are available. In the epithelia of the cesophagus and the forestomach ( $S$-phase $=$ about $8 \mathrm{~h}$ (ref. 4 ); $G_{2}$-phase $=$ several h (ref. $5)$ the actually observed intervals of $12 \mathrm{~h}$ would be understandable in this way.

Furthermore, the experiments show (Table 1) that the duration of the period during which the mitotic index is at a maximum is approximately equal to the period during which the tritium index is at a maximum. (In some cell types the length of the mitotic index maximum might be somewhat shorter than that of the tritium index). In addition, the degre of fluctuation is about the same in both cases. This, too, is understandable if it is assumed that the length of the synchronization wave is approximately equal to the $S$-phase duration.

Equally great fluctuations of the tritium index were found in the ear epidermis. The interval between the maxima of the indices, however, was only a few hours (possibly plus any multiple of $24 \mathrm{~h}$ ). These cells are also exceptional in that the duration of their $S$-phase is clearly longer than that in other tissues ${ }^{6}$. Further work on these cells might prove to be of special significance for the explanation of the phenomena of synchronization.

The experiments indicate that the causes of the fluctuation in the mitotic rate are obviously more complex than has been hitherto assumed. They can probably be interpreted, at least partially, as the result of a partial synchronization of $S$-phases.

In several publications the duration of the generation cycle has been deduced from the tritium index or from the mitotic index? ${ }^{7}$ However, this is only possible in the case of a completely asynchronous cell population, that is when the cells are distributed uniformly throughout the different phases of the generation-cycle. The diurnal fluctuations in the number of cells in the $S$-phase described here show that this assumption may be unwarranted.

${ }^{1}$ Bullough, W. S., Biol. Rev., 27, 133 (1952).

¿ Bullough W. S., Biol. Rev., 37, 307 (1962).

\& Bertalanffy, F. D., Acta Anat., 40, 130 (1960).

- Pilgrim, C., and Maurer, W. (to be published).

soburg, E., and Maurer, W., Biochim. Biophys. Acta, 61, 229 (1962).

s Sherman, F. G., Quastler, H., and Wimber, D. R., Exp. Cell Res., 25, 114 (1961). R., and Kisieleski, W. E., Atompraxis, 8, 386 (1962). 